\title{
Thymulin-Based Gene Therapy and Pituitary Function in Animal Models of Aging
}

\author{
Paula C. Reggiani ${ }^{a, b} \quad$ Brenda Poch ${ }^{a, b}$ Gloria M. Cónsole ${ }^{b}$ Omar J. Rimoldi ${ }^{a}$ \\ Jose I. Schwerdt ${ }^{a}$ b Victoria Tüngler ${ }^{b, c}$ Margarita M. Garcia-Bravo ${ }^{a}$ \\ Mireille Dardenne ${ }^{d}$ Rodolfo G. Goya ${ }^{a, b}$

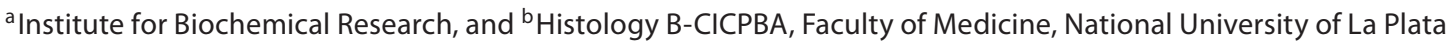 \\ (UNLP), La Plata, Argentina; ' Institut für Pharmakologie und Toxikologie, Charité-Universitätsmedizin, Berlin, \\ Germany; ${ }^{\text {d} C N R S ~ U M R ~ 8147, ~ U n i v e r s i t e ́ ~ P a r i s ~ D e s c a r t e s, ~ H o ̂ p i t a l ~ N e c k e r, ~ P a r i s, ~ F r a n c e ~}$
}

\section{Key Words}

Thymulin - Neuroendocrine control $\cdot$ Hypophysiotropic activity - Gene therapy - Regulatable adenovectors · Anti-inflammatory properties $\cdot$ Ovarian dysgenesis

\begin{abstract}
Thymulin is a thymic hormone exclusively produced by the thymic epithelial cells. After its discovery and initial characterization in the 1970s, it was demonstrated that thymulin production and secretion is strongly influenced by the neuroendocrine system. Conversely, a growing core of information, to be reviewed here, points to thymulin as a hypophysiotropic peptide. Additionally, thymulin was shown to possess anti-inflammatory and analgesic properties in the brain. In recent years, a synthetic DNA sequence coding for a biologically active analog of thymulin, metFTS, was constructed and cloned in different adenoviral vectors. These include bidirectional regulatable Tet-Off vector systems that simultaneously express metFTS and green fluorescent protein and that can be downregulated reversibly by the addition of the antibiotic doxycycline. A number of recent studies suggest that thymulin gene therapy may be a suitable therapeutic strategy to prevent some of the endocrine and reproductive
\end{abstract}

\section{KARGER}

(C) 2011 S. Karger AG, Basel

Fax +4161306 1234 E-Mail karger@karger.ch www.karger.com www.karger.com/nim alterations that typically appear in congenitally athymic (nude) mice, taken as a suitable model of neuroendocrine and reproductive aging. The present article briefly reviews the literature on the physiology of the thymulin-pituitary axis as well as on the new molecular tools available to exploit the therapeutic potential of thymulin.

Copyright $\odot 2011$ S. Karger AG, Basel

\section{The Endocrine Thymus and Thymulin}

In mammals, the interaction of the thymus gland with the neuroendocrine system seems to be particularly important during perinatal life, when the thymus and the neuroendocrine system influence the maturation of each other [1]. This was initially suggested by early findings showing that in species in which neonatal thymectomy does not produce any evident impairment of the immune capacity [2], neuroendocrine functions are already highly developed at birth [3]. In mice, the importance of the

Paula C. Reggiani and Brenda Poch contributed equally to this work.
Rodolfo G. Goya

INIBIOLP, Faculty of Medicine, UNLP, CC 455

La Plata 1900 (Argentina)

Tel. +54221 4256735

E-Mail rgoya@netverk.com.ar 
thymus for a proper maturation of the neuroendocrine system is revealed by the endocrine alterations caused by neonatal thymectomy or congenital absence of the thymus. In effect, congenitally athymic (nude) female mice show significantly reduced levels of circulating and pituitary gonadotropins, a fact that seems to be causally related with a number of reproductive derangements described in these mutants [4]. Thus, in homozygous $\mathrm{(nu} /$ $\mathrm{nu}$ ) females, the times of vaginal opening and first ovulation are delayed [5], fertility is reduced [4] and follicular atresia is increased such that premature ovarian failure results [6]. Similar abnormalities result from neonatal thymectomy of normal female mice $[7,8]$. Ovaries of athymic mice respond normally to exogenous gonadotropins, suggesting that the defect is at the level of the hypothalamo-pituitary axis $[9,10]$. In homozygous adult nude CD-1 male mice, thyrotropin, prolactin (PRL), growth hormone $(\mathrm{GH})$ and gonadotropin responses to immobilization and cold stress are reduced as are serum basal levels of the same hormones as compared to the heterozygous counterparts [11-13]. A functional impairment of the hypothalamo-adrenal axis has been reported in nude mice suggesting that humoral thymic factors may play a role in the maturation of this axis [14].

Thymulin is a thymic metallopeptide involved in several aspects of intra- and extrathymic T cell differentiation [15]. Thymulin, which is exclusively produced by the thymic epithelial cells (TEC) [16], consists of a biologically inactive nonapeptide component termed FTS (an acronym for serum thymus factor in French), coupled in an equimolecular ratio to the ion zinc [17], which confers biological activity to the molecule [18]. The metallopeptide active form bears a specific molecular conformation that has been evidenced by nuclear magnetic resonance [19].

\section{Neuroendocrine Control of Thymulin Production}

Thymulin exerts a controlling feedback effect on its own secretion both in vivo and in vitro [20,21]. Additionally, thymulin production and secretion is influenced directly or indirectly by the neuroendocrine system [22]. A particularly relevant pituitary hormone is $\mathrm{GH}$ which can influence thymulin synthesis and secretion. In vitro, human GH can stimulate thymulin release from TEC lines [23] which are known to possess specific receptors for $\mathrm{GH}$ [24]. Animal studies have shown that treatment of aged dogs with bovine GH partially restored their low thymulin serum levels [25]. In old mice, treatment with ovine
GH increased their low circulating thymulin levels and enhanced the concanavalin-A-dependent proliferative response of their thymocytes, as well as interleukin- 6 production [26]. In old rats, combined treatment with GH and thyroxine $\left(\mathrm{T}_{4}\right)$ was also able to partially restore their reduced thymulin levels [27]. In clinical studies, it was reported that in congenitally GH-deficient children, who consistently exhibited low plasma thymulin levels, GH therapy succeeded in increasing thymic hormone levels to near-normal values [28]. Acromegalic middle-aged patients have elevated thymulin serum levels compared to age-matched normal subjects $[23,28]$. It is likely that these effects of GH are mediated, at least in part, by insulin-like growth factor 1 as suggested by the fact that the $\mathrm{GH}$-induced enhancement of thymulin production could be prevented by previous treatment with antibodies against insulin-like growth factor 1 or insulin-like growth factor 1 receptor [23].

There is also evidence for a PRL-thymulin axis. Thus, it is known that TEC possess PRL receptors [29] and that PRL can stimulate thymulin synthesis and secretion both in vitro and in vivo [30]. Furthermore, administration of PRL to old mice elevated their reduced circulating levels of thymulin [30].

The thyroid axis also influences thymulin secretion. Thus, $\mathrm{T}_{4}$ has been shown to stimulate thymulin synthesis and secretion in mice [31]. In vivo treatment of mice with triiodothyronine enhanced thymulin secretion whereas treatment of the animals with propylthiouracil, an inhibitor of thyroid hormone synthesis, decreased their circulating thymulin levels [32]. In humans, hyperthyroidism brings about an increase in circulating thymulin levels whereas hypothyroid patients show depressed levels of this thymic hormone [33]. In in vitro studies, it was shown that thyroid hormones stimulate thymulin secretion by a direct action on TEC $[34,35]$. Interestingly, it has been shown that treatment of aged animals with $\mathrm{T}_{4}$ can reverse their decreased thymulin levels [31].

Although there are no studies documenting a direct effect of gonadotropins or adrenocorticotropic hormone on thymulin secretion, gonadectomy or adrenalectomy in mice are known to induce a transient decrease in serum thymulin levels [36]. This effect is potentiated by the simultaneous removal of the adrenals and gonads [36]. In TEC cultures, it was shown that exposure to physiological levels of glucocorticoids or gonadal steroids enhanced thymulin concentration in the cell supernatants [37].

Although there is no rigorous evidence proving the existence of hypothalamic factors able to influence thymulin production by a direct action on TEC, there are 


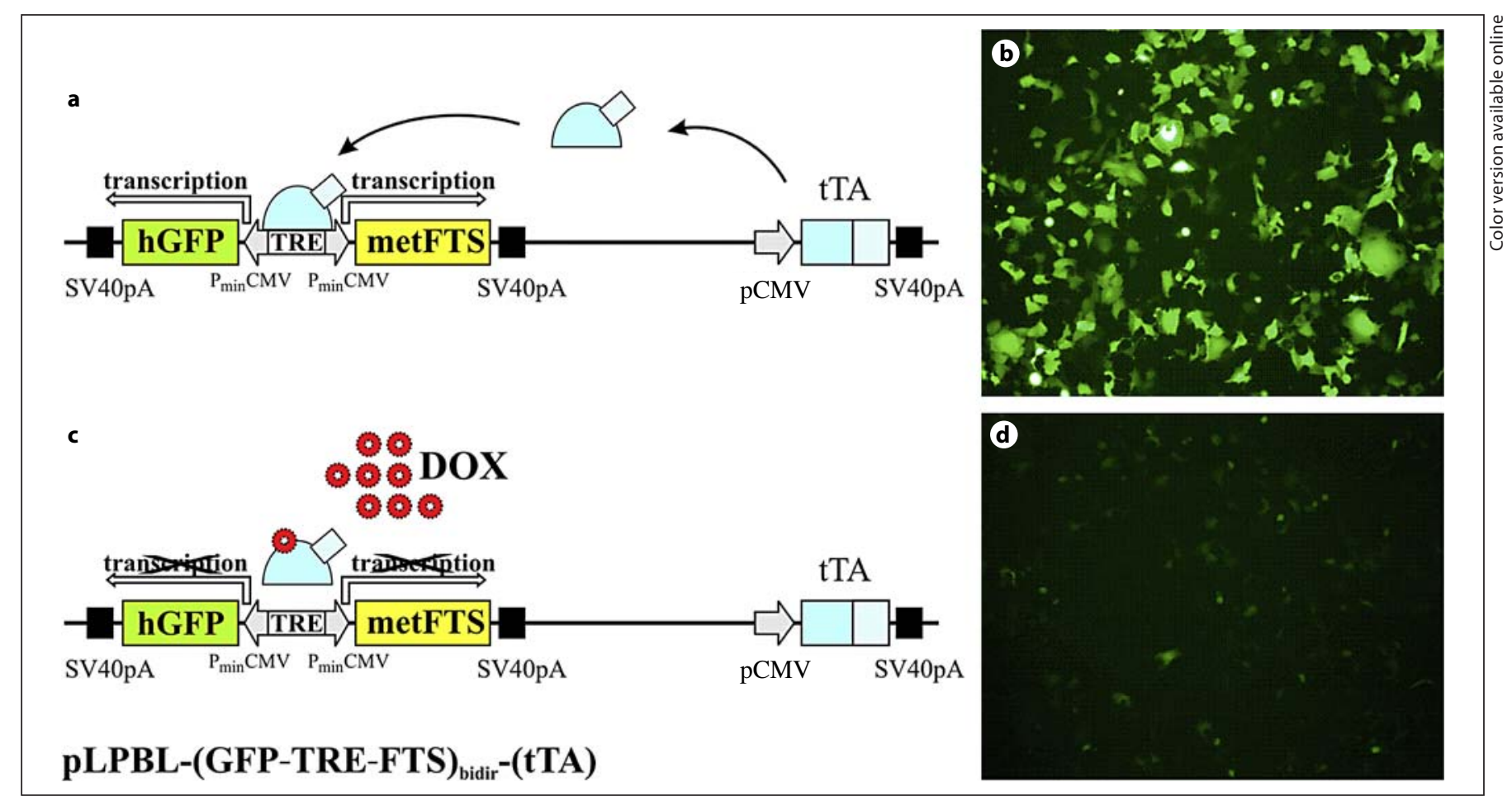

Fig. 1. Diagrammatic representation of the genome of a regulatable bidirectional Tet-Off plasmid system expressing the genes for GFP and metFTS. It harbors two expression cassettes: the pCMVtTA cassette (right portion of the genome) expresses the chimeric regulatory protein tTA, which binds to the regulatable bidirectional promoter of the bidirectional cassette hGFP-TRE-metFTS (left portion of the genome) and activates it inducing the expression of the transgenes for hGFP and metFTS. a The active system

two studies which suggest that this may be the case. Treatment of old mice with hypothalamic extracts from young mice resulted in reappearance of detectable levels of circulating thymulin [38]. Hypothalamic and pituitary extracts from young mice stimulated thymulin release from TEC cultures but this stimulation declined when the pituitary and hypothalamic extracts were obtained from old mice [39].

\section{Hypophysiotropic Activity of Thymulin}

The multilateral influence that the neuroendocrine system exerts on thymulin secretion suggests that this metallopeptide could in turn be part of a feedback loop acting on neuroendocrine structures. This possibility is now supported by a significant body of evidence indicating that thymulin possesses hypophysiotropic activity. (in the absence of DOX). c The system now inhibited by DOX. TRE = Tetracycline-responsive element; metFTS = metFTS coding sequence; $\mathrm{tTA}=$ chimeric regulatory protein; $\mathrm{P}_{\min } \mathrm{CMV}=\mathrm{cy}-$ tomegalovirus minimal promoter; $\mathrm{SV} 40 \mathrm{pA}=$ polyadenylation signal. Images correspond to HEK293 cells transfected with a plasmid harboring the Tet-Off system for metFTS and GFP in the absence $(\mathbf{b})$ or in the presence $(\mathbf{d})$ of DOX. Magnification: $\times 20$.

Thus, thymulin has been shown to stimulate luteinizing hormone (LH) release from perfused rat pituitaries [40] and adrenocorticotropic hormone from incubated rat pituitary fragments, the latter being an effect mediated by intracellular cyclic adenosine monophosphate and cyclic guanosine monophosphate accumulation [41]. In an in vitro study using pituitary cells obtained from female rats in different days of the estrous cycle it was observed that thymulin modulates the stimulatory activity of gonadotropin-releasing hormone on $\mathrm{LH}$ and follicle-stimulating hormone release [42]. Thymulin has been found to stimulate GH, PRL, thyrotropin and gonadotropin release in dispersed rat pituitary cells at doses from $10^{-8}$ to $10^{-3} \mathrm{M}$ [43-45], whereas others have reported that thymulin doses of $10^{-11} \mathrm{M}$ stimulate $\mathrm{LH}$, inhibit PRL release and have no effect on GH secretion in incubated rat pituitary fragments [41]. The stimulatory effect of thymulin on hormone release in rat pituitary cells declines with the age of 


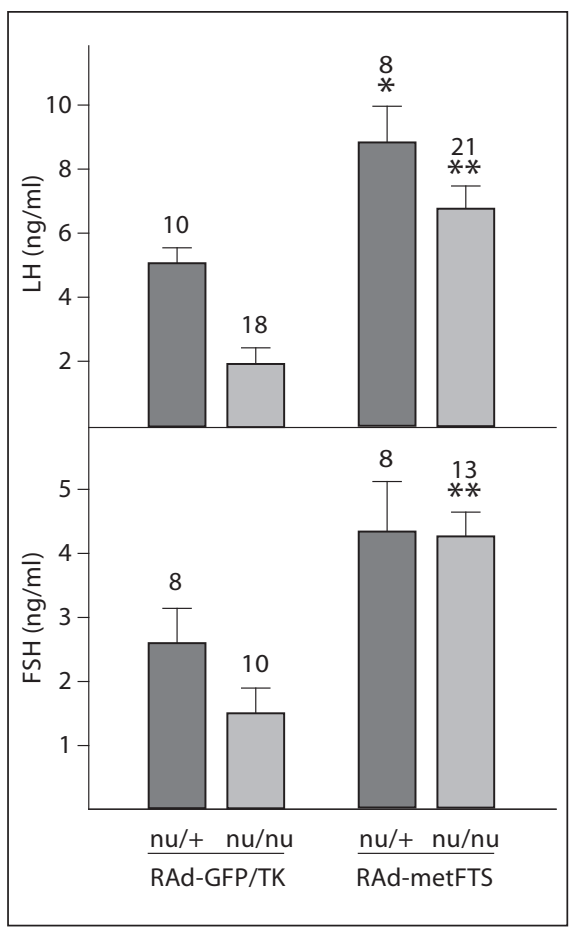

Fig. 2. Effect of neonatal thymulin gene therapy on serum LH and follicle-stimulating hormone (FSH) in nude mice. The indicated vectors were intramuscularly injected at birth and the animals were bled 51-52 days afterwards for serum LH and follicle-stimulating hormone determination. Significance of differences between RAd-GFP-injected animals (placebo) and RAd-metFTSinjected counterparts are indicated by ${ }^{*} \mathrm{p}<0.05$ or ${ }^{* *} \mathrm{p}<0.01$. Image used with permission [52].

the cell donor, which suggests that aging brings about a desensitization of the pituitary gland to thymic signals [43-45].

There is in vitro and in vivo evidence suggesting that thymulin plays a role in the regulation of female spontaneous puberty, possibly through effects on pituitary gonadotropin release and ovarian steroidogenesis [40, 42, 46-48]. Thymulin also modulates gonadotropin-induced testicular steroidogenesis [49].

Immunoneutralization studies have strengthened the hypothesis that thymulin is a physiologic mediator of the perinatal influence of the thymus on neuroendocrine maturation. Thus, neonatal immunoneutralization of circulating thymulin in otherwise normal C57BL/6 mice induced significant morphologic alterations in most anterior pituitary endocrine cell populations $[50,51]$ as well as a reduction in circulating levels of gonadotropins, thyrotropin, PRL and GH [51, 52; unpubl. obs.].

Thymulin Gene Therapy in the Pituitary

\section{Construction of Synthetic Genes for Thymulin}

The prospect of implementing thymic hormone gene therapy appears as an interesting avenue of research aimed at restoring endocrine thymic activity when thymus function is compromised. However, none of the genes coding for the known thymic peptides has been cloned, a situation that hinders the implementation of gene or other molecular therapies for thymic hormones. It was suggested that a possible way to overcome this problem could be to construct 'artificial genes' coding for those thymic peptides whose amino acid sequences were short and required no posttranslational processing [53]. This was achieved for thymulin and the corresponding DNA sequence was initially cloned in a bacterial plasmid [54]. More recently, a DNA sequence coding for the biologically active FTS analog called metFTS was constructed and cloned in an adenoviral vector termed RAd-metFTS [55].

When intramuscularly administered to thymectomized mice and rats (whose circulating levels of thymulin are nondetectable), RAd-metFTS induced sustained supraphysiological serum levels of biologically active thymulin which remained high for at least 112 days in mice [55] and for over 320 days in rats. Interestingly, adenovirally mediated expression of the synthetic gene for metFTS in the substantia nigra and hypothalamus of adult thymectomized rats had a significantly longer duration than adenovirally mediated expression of the gene for green fluorescent protein (GFP) or Escherichia coli $\beta$-galactosidase in the same brain regions [56]. This phenomenon could be due to the anti-inflammatory activity in the brain reported for thymulin and some thymulin analogs $[57,58]$. The anti-inflammatory activity could prevent the immune system of the vector-injected animals from mounting a destructive response against the transduced cells. The same rationale could explain the longterm persistence of high concentrations of recombinant metFTS in the circulation of RAd-metFTS-injected thymectomized rodents [55].

\section{Regulatable Adenovectors for Thymulin}

The first adenovector harboring the metFTS sequence (RAd-metFTS) expressed its transgene constitutively [55]. More recently, a Tet-Off regulatable bidirectional plasmid system expressing the genes for humanized green fluorescent protein (hGFP) and metFTS was constructed [unpubl. obs.]. It harbors two expression cas- 
settes: a pCMV-tTA cassette that expresses the chimeric regulatory protein $\mathrm{tTA}$, which binds to the regulatable bidirectional promoter of the bidirectional cassette hGFP-TRE-metFTS and activates it, thus inducing the expression of the transgenes for hGFP and metFTS. If the antibiotic doxycycline (DOX) is added to the medium, it binds to an allosteric site on the tTA protein and causes it to dissociate from the regulatable promoter thus turning off transgene expression (fig. 1). A two-viral vector version of this system was also constructed. It consists of two adenoviral vectors; one, RAd-tTA, expresses the tTA regulatory protein and the other, RAd-(hGFP-TREmetFTS $)_{\text {bidir }}$ expresses the bidirectional regulatable cassette for GFP and metFTS. When a cell is cotransduced by both vector components, RAd-tTA expresses the tTA regulatory protein, which binds to the regulatable promoter $\left(\mathrm{P}_{\min } \mathrm{CMV}\right.$-TRE- $\left.\mathrm{P}_{\min } \mathrm{CMV}\right)$ of the second vector and activates the expression of both transgenes. If DOX is added to the medium, it inhibits transgene expression by the mechanism described above. The system was successfully tested in cell lines and in the brain and muscle [unpubl. obs.].

These bidirectional vectors allow a ready visualization of metFTS expression in tissues and organs by fluorescence microscopy (if GFP is expressed, then metFTS also is because they are under the control of a single promoter). The regulatability by DOX of these vectors allows the experimenter to turn off and on transgene expression in vivo by respectively adding or removing DOX from the drinking water.

\section{Neonatal Gene Therapy for Thymulin in Nude Mice}

A single intramuscular injection of RAd-metFTS in newborn nude mice (nude mice have undetectable circulating levels of thymulin) elicited long-term restoration of serum thymulin in these mutants. This treatment was able to prevent the deficits in serum LH and follicle-stimulating hormone that typically appear in adult female nudes (fig. 2) [52]. Furthermore, neonatal thymulin gene therapy (NTGT) in nude female mice has been found to significantly prevent the ovarian dysgenesis that usually develops in 70-day-old female nude mice [59].

In nude mice, NTGT has also been shown to partially prevent the alterations of some of the endocrine cell populations that occur in these mutants after puberty. Thus, NTGT prevented the reduction in the number of gonadotrophs, thyrotrophs and corticotrophs in adult nudes $[51,60,61]$. NTGT also prevented, to a varying extent, changes in other histomorphometric parameters in the anterior pituitary of adult nudes. Thymulin administration to nudes marginally decreased their hypothalamic content of corticotropin-releasing hormone and slightly increased the adrenal content of corticosterone of these mutants [61]. NTGT had the highest histomorphometric impact on the gonadotrophic population of nudes [60].

\section{Concluding Remarks}

Thymulin is probably the best characterized of all putative thymic hormones and seems to play a physiologic role in thymus-pituitary communication, particularly during perinatal life. Interest in the therapeutic use of thymulin flourished during the 1970s and 1980s when efforts were almost exclusively focused on using thymulin (and other thymic peptides) for the treatment of autoimmune and other immunopathologies as well as cancer $[62,63]$. Subsequent studies, most of them carried out during the last 18 years, established that thymulin is active on the hypophysis and the brain. This awareness and the recent availability of a synthetic gene for metFTS as well as sophisticated viral vectors have opened new avenues for the exploration and eventual exploitation of the therapeutic potential of this metallopeptide.

\section{Acknowledgments}

Part of the work from our laboratory reviewed here was supported by NIH grant No. R01AG029798-3, ANPCYT grant No. PICT08-36938214 and CONICET grant PIP2378 to R.G.G. and by the Argentine Research Council and the Institut National de la Santé et de la Recherche Médicale (INSERM), France to M.D. and R.G.G.

References $\quad>_{1}$ Goya RG: The immune-neuroendocrine homeostatic network and aging. Gerontology 1991;37:208-213.

2 Solomon JB: Ontogeny of defined immunity in mammals; in Neuberger A, Tatum EL (eds): Foetal and Neonatal Immunology. Frontiers of Biology. New York, American Elsevier Publishing Co, 1971, vol 20, pp 234306.

3 Jost A: The extent of foetal and endocrine autonomy; in Wolstenholme GEW, O'Connor M (eds): Foetal Autonomy. Ciba Foundation Symposium. London, J\&A Churchill Ltd, 1969, pp 79-94. 
-4 Rebar RW, Morandini IC, Erickson GF, Petze JE: The hormonal basis of reproductive defects in athymic mice: diminished gonadotropin concentrations in prepubertal females. Endocrinology 1981;108:120-126.

$\checkmark 5$ Besedovsky HO, Sorkin E: Thymus involvement in female sexual maturation. Nature 1974;249:356-358.

6 6 Lintern-Moore S, Pantelouris EM: Ovarian development in athymic nude mice. The size and composition of the follicle population. Mech Ageing Dev 1975;4:385-390.

7 Michael SD, Taguchi O, Nishizuka Y: Effects of neonatal thymectomy on ovarian development and plasma LH, FSH, GH and PRL in the mouse. Biol Reprod 1980;22:343-350.

8 Nishizuka Y, Sakakura T: Ovarian dysgenesis induced by neonatal thymectomy in the mouse. Endocrinology 1971;89:889-893.

$\checkmark 9$ Pierpaoli W, Besedovsky HO: Role of the thymus in programming of neuroendocrine functions. Clin Exp Immunol 1975;20:323328.

10 Lintern-Moore S, Pantelouris EM: Ovarian development in athymic nude mice. 3 . The effect of PMSG and oestradiol upon the size and composition of the ovarian follicle population. Mech Ageing Dev 1976;5:33-38.

- 11 Goya RG, Cónsole GM, Sosa YE, Gómez Dumm CL, Dardenne M: Altered functional responses with preserved morphology of gonadotrophic cells in congenitally athymic mice. Brain Behav Immun 2001;15:85-92.

-12 Goya RG, Sosa YE, Cónsole GM, Dardenne $\mathrm{M}$ : Altered thyrotropic and somatotropic responses to environmental challenges in congenitally athymic mice. Brain Behav Immun 1995;9:79-86.

-13 Goya RG, Sosa YE, Cónsole GM, Dardenne $\mathrm{M}$ : Altered regulation of serum prolactin in nude mice. Med Sci Res 1996;24:279-280.

- 14 Daneva T, Spinedi E, Hadid R, Gaillard RC: Impaired hypothalamo-pituitary-adrenal axis function in Swiss nude athymic mice. Neuroendocrinology 1995;62:79-86.

15 Bach JF: Thymulin (FTS-Zn). Clin Immunol Allergy 1983;3:133-156.

- 16 Dardenne M, Papiernik M, Bach JF, Stutman O: Studies on thymus products. 3. Epithelial origin of the serum thymic factor. Immunology 1974;27:299-304.

-17 Gastinel LN, Dardenne M, Pléau JM, Bach JF: Studies on the zinc-binding site to the serum thymic factor. Biochim Biophys Acta 1984;797:147-155.

- 18 Dardenne M, Pléau JM, Nabarra B, Lefrancier P, Derrien M, Choay J, Bach JF: Contribution of zinc and other metals to the biological activity of serum thymic factor. Proc Natl Acad Sci USA 1982;79:5370-5373.

-19 Cung MT, Marraud M, Lefrancier P, Dardenne M, Bach JF, Laussac JP: NMR study of a lymphocyte differentiating thymic factor. An investigation of the $\mathrm{Zn}$ (II)-nonapeptide complexes (thymulin). J Biol Chem 1988;263:5574-5580.
20 Savino W, Dardenne M, Bach JF: Thymic hormones containing cells. 3. Evidence for a feed-back regulation of the secretion of the serum thymic factor (FTS) by thymic epithelial cells. Clin Exp Immunol 1983;52:7-12.

21 Cohen S, Berrih S, Dardenne M, Bach JF: Feed-back regulation of the secretion of a thymic hormone (thymulin) by human thymic epithelial cells in culture. Thymus 1986; 8:109-119.

22 Savino W, Dardenne M: Neuroendocrine control of thymus physiology. Endocr Rev 2000;21:412-443.

23 Timsit J, Savino W, Safieh B, Chanson P, Gagnerault MC, Bach JF, Dardenne M: GH and IGF-I stimulate hormonal function and proliferation of thymic epithelial cells. J Clin Endocrinol Metab 1992;75:183-188.

24 Ban E, Gagnerault MC, Jammes H, PostelVinay MC, Haour F, Dardenne M: Specific binding sites for growth hormone in cultured mouse thymic epithelial cells. Life Sci 1991;48:2141-2148.

25 Goff BL, Roth JA, Arp LH, Incefy GS: Growth hormone treatment stimulates thymulin production in aged dogs. Clin Exp Immunol 1987;68:580-587.

26 Goya RG, Gagnerault MC, De Moraes MC Savino W, Dardenne M: In vivo effects of growth hormone on thymus function in aging mice. Brain Behav Immun 1992;6:341354.

27 Goya RG, Gagnerault MC, Sosa YE, Bevilacqua JA, Dardenne M: Effects of growth hormone and thyroxine on thymulin secretion in aging rats. Neuroendocrinology 1993;58: 338-343.

28 Mocchegiani E, Paolucci P, Balsamo A, Cacciari E, Fabris N: Influence of growth hormone on thymic endocrine activity in humans. Horm Res 1990;33:248-255.

29 Dardenne M, Kelly PA, Bach JF, Savino W: Identification and functional activity of prolactin receptors in thymic epithelial cells. Proc Natl Acad Sci USA 1991;88:9700-9704.

-30 Dardenne M, Savino W, Gagnerault MC, Itoh T, Bach JF: Neuroendocrine control of thymic hormonal production. 1. Prolactin stimulates in vivo and in vitro the production of thymulin by human and murine thymic epithelial cells. Endocrinology 1989;125: 3-12.

31 Fabris N, Mocchegiani E: Endocrine control of thymic serum factor production in young adult and old mice. Cell Immunol 1985;91: 325-335.

32 Savino W, Wolf B, Aratan-Spire S, Dardenne M: Thymic hormone containing cells. 4 Fluctuations in the thyroid hormone levels in vivo can modulate the secretion of thymulin by the epithelial cells of young mouse thymus. Clin Exp Immunol 1984;55:629-635.

-33 Fabris N, Mocchegiani E, Mariotti S, Pacini F, Pinchera A: Thyroid function modulates thymic endocrine activity. J Clin Endocrino Metab 1986;62:474-478.
34 Villa-Verde DM, de Mello-Coelho V, Fariasde-Oliveira DA, Dardenne M, Savino W: Pleiotropic influence of triiodothyronine on thymus physiology. Endocrinology 1993; 133:867-875.

35 Mocchegiani E, Amadio L, Fabris N: Neuroendocrine-thymus interactions. 1. In vitro modulation of thymic factor secretion by thyroid hormones. J Endocrinol Invest 1990; 13:139-147.

36 Dardenne M, Savino W, Duval D, Kaiserlian D, Hassid J, Bach JF: Thymic hormone-containing cells. 7. Adrenals and gonads control the in vivo secretion of thymulin and its plasmatic inhibitor. J Immunol 1986;136:13031308

37 Savino W, Bartoccioni E, Homo-Delarche F, Gagnerault MC, Itoh T, Dardenne M: Thymic hormone containing cells. 9. Steroids in vitro modulate thymulin secretion by human and murine thymic epithelial cells. J Steroid Biochem 1988;30:479-484.

>38 Folch H, Eller G, Mena M, Esquivel P: Neuroendocrine regulation of thymus hormones: hypothalamic dependence of 'facteur thymique serique' level. Cell Immunol 1986; 102:211-216.

39 Goya RG, Gagnerault MC, Sosa YE, Dardenne M: Reduced ability of hypothalamic and pituitary extracts from old mice to stimulate thymulin secretion in vitro. Mech Ageing Dev 1995;83:143-154.

40 Zaidi SA, Kendall MD, Gillham B, Jones MT: The release of $\mathrm{LH}$ from pituitaries perifused with thymic extracts. Thymus 1988-1989; 12:253-264.

41 Hadley AJ, Rantle CM, Buckingham JC: Thymulin stimulates corticotrophin release and cyclic nucleotide formation in the rat anterior pituitary gland. Neuroimmunomodulation 1997;4:62-69.

42 Hinojosa L, García L, Domínguez R, Romano MC, Damián-Matsumura PG, Castillo L, Rosas P: Effects of thymulin and GnRH on the release of gonadotropins by in vitro pituitary cells obtained from rats in each day of estrous cycle. Life Sci 2004;76:795-804.

43 Brown OA, Sosa YE, Bolognani F, Goya RG: Thymulin stimulates prolactin and thyrotropin release in an age-related manner. Mech Ageing Dev 1998;104:249-262.

-44 Brown OA, Sosa YE, Dardenne M, Pléau J, Goya RG: Growth hormone-releasing activity of thymulin on pituitary somatotropes is age dependent. Neuroendocrinology 1999; 69:20-27.

45 Brown OA, Sosa YE, Dardenne M, Pléau JM, Goya RG: Studies on the gonadotropin-releasing activity of thymulin: changes with age. J Gerontol A Biol Sci Med Sci 2000; 55:B170-B176.

46 Hinojosa L, Chavira R, Dominguez R, Rosas $\mathrm{P}$ : Effects of thymulin on spontaneous puberty and gonadotrophin-induced ovulation in prepubertal normal and hypothymic mice. J Endocrinol 1999;163:255-260. 
-47 García L, Hinojosa L, Domínguez R, Chavira R, Rosas P: Effects of infantile thymectomy on ovarian functions and gonadotrophininduced ovulation in prepubertal mice: role of thymulin. J Endocrinol 2000;166:381-387.

-48 García L, Hinojosa L, Domínguez R, Chavira $\mathrm{R}$, Rosas P: Effects of injecting thymulin into the anterior or medial hypothalamus or the pituitary on induced ovulation in prepubertal mice. Neuroimmunomodulation 2005; 12:314-320.

49 Wise T: In vitro and in vivo effects of thymulin on rat testicular steroid synthesis. J Steroid Biochem Mol Biol 1998;66:129-135.

-50 Camihort G, Luna G, Vesenbeckh S, Ferese C, Dardenne M, Goya R, Cónsole G: Morphometric assessment of the impact of serum thymulin immunoneutralization on pituitary cell populations in peripubertal mice. Cells Tissues Organs 2006;184:23-30.

-51 Martines EV, Reggiani PC, Schwerdt JI, Goya RG, Cónsole GM: Thymulin gene therapy prevents the histomorphometric changes induced by thymulin deficiency in the thyrotrope population of mice. Cells Tissues Organs 2011;194:67-75

52 Goya RG, Reggiani PC, Vesenbeckh SM, Pléau JM, Sosa YE, Cónsole GM, Schade R, Henklein P, Dardenne M: Thymulin gene therapy prevents the reduction in circulating gonadotropins induced by thymulin deficiency in mice. Am J Physiol Endocrinol Metab 2007;293:E182-E187.
53 Goya RG, Cónsole GM, Hereñú CB, Brown OA, Rimoldi OJ: Thymus and aging: potential of gene therapy for restoration of endocrine thymic function in thymus-deficient animal models. Gerontology 2002;48:325328.

54 Calenda A, Cordonnier A, Lederer F, Le DKH, Pleau JM: Production of biologically active thymulin in Escherichia coli through expression of a chemically synthesized gene. Biotechnol Lett 1988;10:155-160.

55 Reggiani PC, Hereñú CB, Rimoldi OJ, Brown OA, Pléau JM, Dardenne M, Goya RG: Gene therapy for long-term restoration of circulating thymulin in thymectomized mice and rats. Gene Ther 2006;13:1214-1221.

56 Morel GR, Brown OA, Reggiani PC, Hereñú CB, Portiansky EL, Zuccolilli GO, Pléau JM, Dardenne M, Goya RG: Peripheral and mesencephalic transfer of a synthetic gene for the thymic peptide thymulin. Brain Res Bull 2006;69:647-651.

57 Safieh-Garabedian B, Dardenne M, Pléau JM, Saadé NE: Potent analgesic and anti-inflammatory actions of a novel thymulin-related peptide in the rat. Br J Pharmacol 2002; 136:947-955.
58 Safieh-Garabedian B, Ochoa-Chaar CI, Poole S, Massaad CA, Atweh SF, Jabbur SJ, Saadé NE: Thymulin reverses inflammatory hyperalgesia and modulates the increased concentration of proinflammatory cytokines induced by icv endotoxin injection. Neuroscience 2003;121:865-873.

59 Reggiani PC, Barbeito CG, Flamini MA, Rodríguez SS, Cónsole GM, Dardenne M, Goya RG: Neonatal thymulin gene therapy prevents the characteristic ovarian atrophy of adult nude mice (abstract). Seventh Meet Int Soc Neuroimmunomodulation, Rio de Janeiro, 2008

60 Reggiani PC, Martines E, Ferese C, Goya R, Console GM: Morphological restoration of gonadotrope population by thymulin gene therapy in nude mice. Histol Histopathol 2009;24:729-735

61 Martínes EV, Reggiani PC, Schwerdt JI, Goya RG, Cónsole GM: Neonatal thymulin gene therapy in nude mice: effects on the morphology of the pituitary corticotrope population. Histol Histopathol 2011;26:471479.

62 Bach JF, Dardenne M, Goldstein AL: Clinical aspects of thymulin (FTS); in Goldstein AL (ed): Thymic Hormones and Lymphokines. Basic Chemistry and Clinical Applications. New York, Plenum Press, 1984, pp 593-600.

63 Sztein MB, Goldstein AL: Thymic hormones - A clinical update. Springer Semin Immunopathol 1986;9:1-18. 